\title{
High-performance liquid chromatographic determination of galanthamine, a long-acting anticholinesterase drug, in serum, urine, and bile
}

\section{Citation for published version (APA):}

Claessens, H. A., Thiel, van, M. J. S., Westra, P., \& Soeterboek, A. M. (1983). High-performance liquid chromatographic determination of galanthamine, a long-acting anticholinesterase drug, in serum, urine, and bile. Journal of Chromatography, 275(2), 345-353. https://doi.org/10.1016/S0378-4347(00)84380-7

DOI:

10.1016/S0378-4347(00)84380-7

Document status and date:

Published: 01/01/1983

Document Version:

Publisher's PDF, also known as Version of Record (includes final page, issue and volume numbers)

\section{Please check the document version of this publication:}

- A submitted manuscript is the version of the article upon submission and before peer-review. There can be important differences between the submitted version and the official published version of record. People interested in the research are advised to contact the author for the final version of the publication, or visit the DOI to the publisher's website.

- The final author version and the galley proof are versions of the publication after peer review.

- The final published version features the final layout of the paper including the volume, issue and page numbers.

Link to publication

\footnotetext{
General rights

- You may freely distribute the URL identifying the publication in the public portal. follow below link for the End User Agreement:

www.tue.nl/taverne

\section{Take down policy}

If you believe that this document breaches copyright please contact us at:

openaccess@tue.nl

providing details and we will investigate your claim.
}

Copyright and moral rights for the publications made accessible in the public portal are retained by the authors and/or other copyright owners and it is a condition of accessing publications that users recognise and abide by the legal requirements associated with these rights.

- Users may download and print one copy of any publication from the public portal for the purpose of private study or research.

- You may not further distribute the material or use it for any profit-making activity or commercial gain

If the publication is distributed under the terms of Article $25 \mathrm{fa}$ of the Dutch Copyright Act, indicated by the "Taverne" license above, please 
Journal of Chromatography, 275 (1983) $345-353$

Biomedical Applications

Elsevier Science Publishers B.V., Amsterdam - Printed in The Netherlands

CHROMBIO. 1676

HIGH-PERFORMANCE LIQUID CHROMATOGRAPHIC DETERMINATION OF GALANTHAMINE, A LONG-ACTING ANTICHOLINESTERASE DRUG, IN SERUM, URINE AND BILE

\section{H.A. CLAESSENS*}

Eindhoven University of Technology, Laboratory of Instrumental Analysis, P.O. Box 513, $5600 \mathrm{MB}$ Eindhoven (The Netherlands)

\section{VAN THIEL}

Eindhoven Diaconessenhuis, Department of Clinical Pharmacy, Eindhoven (The Netherlands)

P. WESTRA

Groningen State University, Institute of Anaesthesiology, Groningen (The Netherlands) and

\section{A.M. SOETERBOEK}

Eindhoven Diaconessenhuis, Department of Clinical Pharmacy, Eindhoven (The Netherlands) (First received December 12th, 1982; revised manuscript received February 9th, 1983)

\section{SUMMARY}

The anticholinesterase drug galanthamine is obtained from alkalinized serum by repeated liquid-liquid extraction. The resulting extract is approximately 100 times concentrated with respect to the original sample. Quantitative determination of galanthamine is performed with normal-phase liquid chromatography using a mixture of dichloromethane- $n$-hexane and ethanolamine as an eluent. Phenacetin is used as internal standard. The absorption of the column effluent is monitored at $235 \mathrm{~nm}$. No endogenous sources of interference have been observed. A galanthamine serum level of $5 \mathrm{ng} / \mathrm{ml}$ is found as the minimum detectable concentration; the coefficient of variation at this level is $37.8 \%(n=4)$. For the assay of galanthamine in the concentration range $10-100 \mathrm{ng} / \mathrm{ml}$, standard deviations vary between 18.9 and $2.5 \%(n=32)$.

\section{INTRODUCTION}

The alkaloid galanthamine hydrobromide is a tertiary amine belonging to 0378-4347/83/\$03.00 1983 Elsevier Science Publishers B.V. 


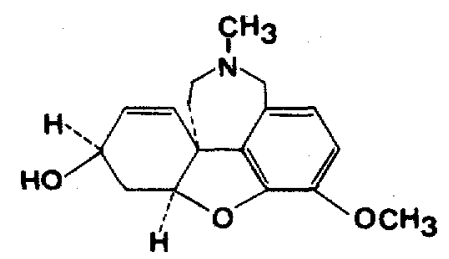

Fig. 1. Structural formula of galanthamine.

the phenanthrene group (see Fig. 1). Since the compound is an anticholinesterase drug, its pharmacological actions are both central and peripheral.

Galanthamine was isolated in 1952 by Proskumina and Yakovleva [1] from the bulbs of the common snowdrop, Galanthus woronowi (Amaryllidaceae family) and in 1956 by Paskow and Iwanova-Bubewa from the bulbs of Galanthus nivalis (see ref. 2). It is available for clinical use as Nivalin (Pharmachim, Sophia, Bulgaria) and as Galanthamine (Medexport, Moscow, U.S.S.R.). Until now, galanthamine has mainly been in clinical use for the reversal of the neuromuscular blockade caused by various curare-like agents [2-5].

Antagonism of the respiratory depressant effect of opiates such as morphine, pethidine, dextromoramide, etc., in both animals and man has also been reported $[6-9]$. Furthermore, galanthamine has been used to reverse the central anticholinergic syndrome caused by scopolamine $[10,11]$ and certain central effects of droperidol and diazepam [12] .

This broad variety of central effects of galanthamine and especially the finding that, in rabbits, the compound reversed opiate-induced respiratory depression, but not the concomitant analgesia [9], makes galanthamine a useful pharmacological tool in the search for better antagonists in anaesthesia.

In further (clinical-)pharmacological studies, concentration-effect relationships will be highly important; therefore, a sensitive and reproducible method for the determination of galanthamine in biological materials has to be developed.

Some work, mostly in the field of thin-layer chromatography, has been done on the assay of galanthamine [13-17]. High-performance liquid chromatographic (HPLC) determination of alkaloids in general has been studied by several authors. Wu and Wittick [18] and Rasmussen et al. [19] describe methods for the separation of alkaloids, using reversed-phase chromatography.

Verpoorte and Baerheim Svendsen [20-22] and Rasmussen et al. [19] report the application of normal-phase chromatography on silica. Also the use of polar bonded phases had been reported [23]. To obtain low detection limits and short analysis times, particle sizes of 5 and $3 \mu \mathrm{m}$ were selected and the capacity factors $\left(k^{\prime}\right)$ of the components of interest were kept below 6 .

The development of the method was started using reversed-phase chromatography on octadecyl phases. In spite of the available tools of this technique we failed to develop a method with the required sensitivity. The application of normal-phase chromatography on $3 \mu \mathrm{m}$ silica gel and a mixture of $n$-hexane-dichloromethane-ethanolamine (500:500:0.25, v/v) as eluent gave good results in terms of detection limit and speed of analysis. The necessary pretreatment of the serum samples was started with extraction columns; however, even extensive experimental work gave no satisfactory results. We found 
a repeated liquid-liquid extraction method very selective, but unfortunately it is more time-consuming.

\section{MATERIALS AND METHODS}

\section{Chemicals}

All chemicals and solvents were of analytical grade (Merck, Darmstadt, G.F.R.). Aqueous solutions were made in double-distilled water.

Dichloromethane and $n$-hexane were both of HPLC grade (Merck) and purified prior to use by filtration through a $0.45-\mu \mathrm{m}$ HVLP membrane (Millipore Corporation, Bedford, MA, U.S.A.).

Galanthamine $\mathrm{HBr}$ and the standard phenacetin were obtained from KochLight Labs. (Colnbrook, Great Britain) and Onderlinge Pharmaceutische Groothandel (Utrecht, The Netherlands), respectively.

\section{Apparatus}

The experiments were performed on a liquid chromatograph consisting of a reciprocating pump (Model 100-A, Beckman Instruments Inc., Berkeley, CA, U.S.A.) and a variable-wavelength UV detector (type Uvidec 100-III, Jasco, Tokyo, Japan) operating at $235 \mathrm{~nm}$ and $2.5 \times 10^{-3}$ a.u.f.s. The pump delivered a constant flow of $1 \mathrm{ml} / \mathrm{min}$. Injections of $10 \mu \mathrm{l}$ were made with an injection valve equipped with a $20-\mu 1$ loop (Model CV-6-UHPa-N60, Valco, Houston, TX, U.S.A.). The reversed-phase columns, $15 \times 0.46 \mathrm{~cm}$, using Polygosil $60-\mathrm{C}_{18} 5 \mu \mathrm{m}$ as packing material (Macherey-Nagel, Düren, G.F.R.) were home-made. The columns were constructed of stainless steel tubing (SS-316, Handy and Harman, Norristown, PA, U.S.A.) $15 \mathrm{~cm} \times 6.4 \mathrm{~mm}$ O.D. $\times 4.6 \mathrm{~mm}$ I.D.

The normal-phase columns, $10 \times 0.46 \mathrm{~cm}$, were pre-packed with CPtm Micro Spher Si $3 \mu \mathrm{m}$ manufactured by Chrompack (Middelburg, The Netherlands).

To suppress the influence of fluctuations of temperature, tubing and column were suitably isolated. Detector signals were registered with a Yew recorder (Yokogawa Electric Works, Tokyo, Japan).

\section{Galanthamine serum standards}

Prepare a stock solution by dissolving $25.64 \mathrm{mg}$ of galanthamine $\mathrm{HBr}$ in $200 \mathrm{ml}$ of water. This solution is equivalent to $10^{5} \mu \mathrm{g}$ of galanthamine base per l. Dilute this solution with blank human serum to make serum standards with final galanthamine concentrations of $5,10,20,40,50,70$, and $100 \mathrm{ng} / \mathrm{ml}$. Serum standard amounts of approximately $5 \mathrm{ml}$ are frozen. There is no degradation of galanthamine after six months of storage at $-20^{\circ} \mathrm{C}$.

\section{Sample preparation}

Pipet $2.0 \mathrm{ml}$ of serum into a $10-\mathrm{ml}$ glass test tube and add $2.0 \mathrm{ml}$ of a $20 \%$ $(\mathrm{w} / \mathrm{v})$ aqueous solution of trichloroacetic acid as protein-precipitating agent. The tube is then rotated on a Vortex mixer for $10 \mathrm{sec}$, allowed to stand at room temperature for $5 \mathrm{~min}$, and centrifuged at $1600 \mathrm{~g}$ for $10 \mathrm{~min}$.

A $3.0-\mathrm{ml}$ aliquot of the supernatant is transferred in a $25-\mathrm{ml}$ glass test tube 
with stopper, and alkalinized by adding $0.6 \mathrm{ml}$ of $4 M$ sodium hydroxide and $2.0 \mathrm{ml}$ of buffer ( $1 M$ ammonia solution titrated with $2 M$ hydrochloric acid to $\mathrm{pH} \mathrm{9.0)}$. Extraction of galanthamine base is carried out twice with $5 \mathrm{ml}$ of dichloromethane (DCM) by Vortex mixing for $2 \mathrm{~min}$ and centrifuging at $1600 \mathrm{~g}$ for $5 \mathrm{~min}$. DCM extracts are transferred to a clean $25-\mathrm{ml}$ glass test tube with stopper and back extracted twice with $5 \mathrm{ml}$ of $0.05 \mathrm{M}$ sulphuric acid by Vortex mixing for $2 \mathrm{~min}$ and centrifuging at $1600 \mathrm{~g}$ for $5 \mathrm{~min}$. Sulphuric acid extracts with galanthamine are transferred to a clean $25-\mathrm{ml}$ glass test tube with stopper and alkalinized by adding $0.4 \mathrm{ml}$ of $4 \mathrm{M}$ sodium hydroxide, and $2.0 \mathrm{ml}$ of buffer $\mathrm{pH} 9.0$, prepared as described above. Subsequently galanthamine base is extracted twice with $5 \mathrm{ml}$ of DCM by Vortex mixing for $2 \mathrm{~min}$ and centrifuging at $1600 \mathrm{~g}$ for $5 \mathrm{~min}$. The DCM phase with galanthamine base, obtained after each extraction, is transferred to a $10-\mathrm{ml}$ conical test tube, containing $0.5 \mathrm{ml}$ of phenacetin internal standard solution in DCM $(12.5 \mu \mathrm{g} / \mathrm{l})$. The organic phase is evaporated under a gentle stream of nitrogen at $50^{\circ} \mathrm{C}$ in a heating bath. The inside wall of the test tube is washed with $0.5-1 \mathrm{ml}$ of DCM, and the DCM is then evaporated to dryness as mentioned above. Each extract is dissolved in $25 \mu$ l of mobile phase by Vortex mixing for $30 \mathrm{sec}$. Then a 10- $\mu$ l aliquot is injected immediately into the chromatograph.

\section{Chromatographic procedures}

The silica column was loaded with ethanolamine by pumping an approximately $0.1 \%$ solution of ethanolamine in $n$-hexane-dichloromethane $(1: 1$,

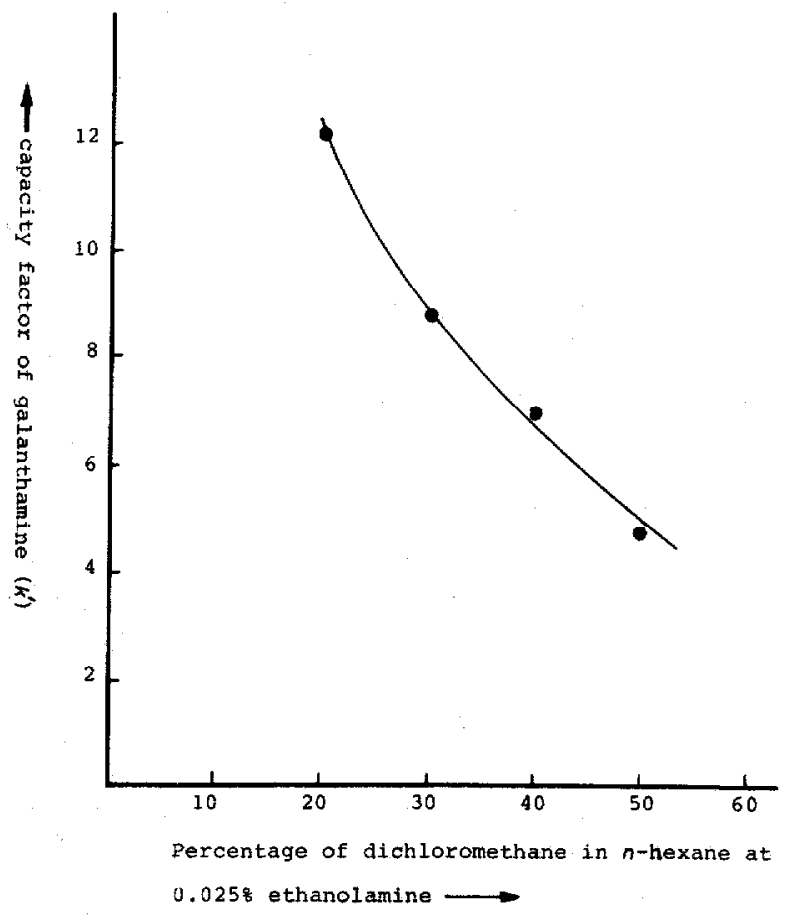

Fig. 2. Influence on the capacity factor $\left(k^{\prime}\right)$ of galanthamine by various percentages of dichloromethane in the eluent mixture consisting of dichloromethane, $n$-hexane and a constant amount of $0.025 \%$ ethanolamine. 


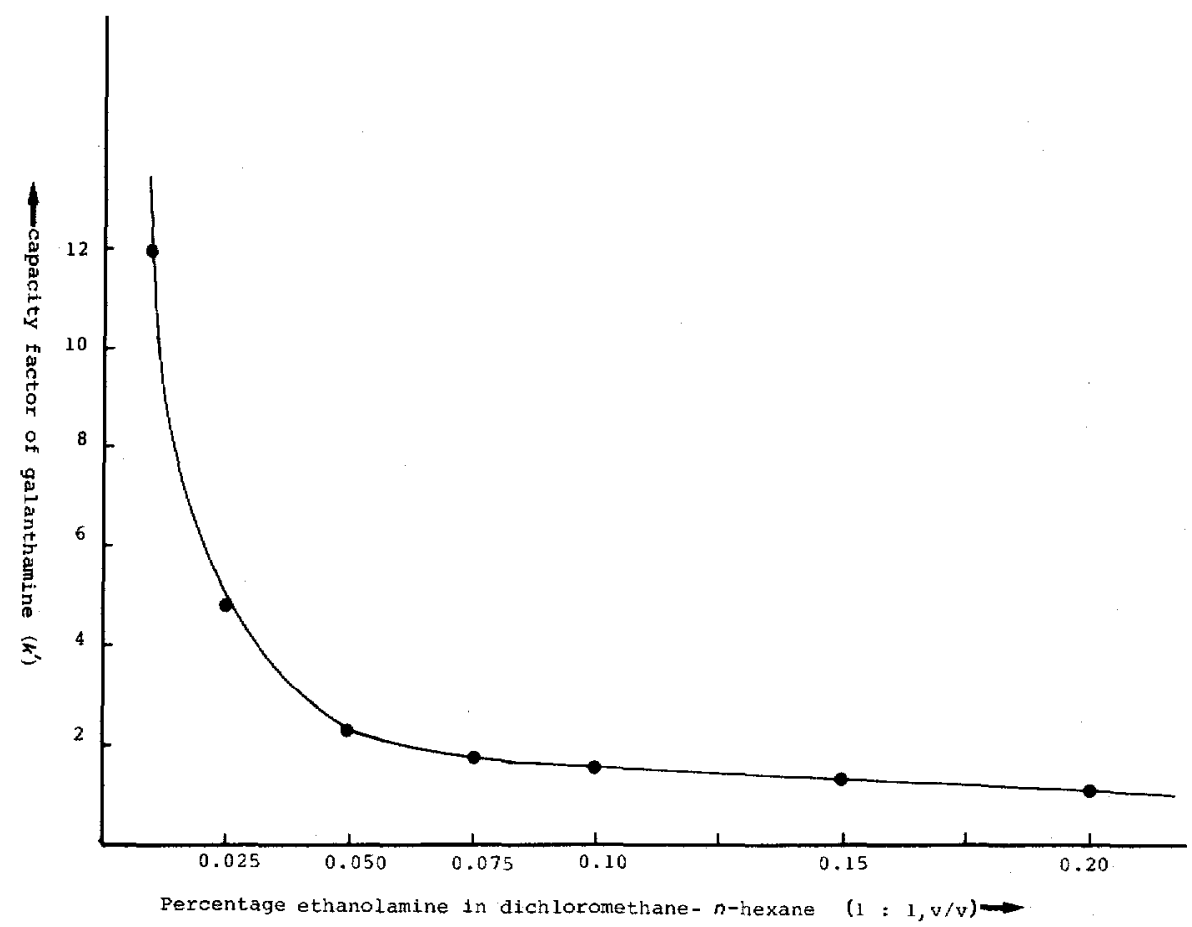

Fig. 3. Influence on the capacity factor $\left(k^{\prime}\right)$ of galanthamine by various amounts of ethanolamine in the eluent mixture consisting of $n$-hexane and dichloromethane $(1: 1, v / v)$.

$\mathrm{v} / \mathrm{v})$ for about $1 \mathrm{~h}$. Then the eluent, dichloromethane- $n$-hexane-ethanolamine $(500: 500: 0.25, v / v)$, was pumped through the system until equilibrium; preferably this was done overnight. The capacity ratio $\left(k^{\prime}\right)$ of galanthamine can be controlled by the content of dichloromethane and ethanolamine as is shown in Figs. 2 and 3, respectively. In practice the control of $k^{\prime}$ by the ethanolamine content is more easy.

The HPLC equipment and conditions described above permit the detector to operate at $235 \mathrm{~nm}$ and $2.5 \times 10^{-3}$ a.u.f.s. Galanthamine has an absorption maximum at $288 \mathrm{~nm}$, and a molar extinction coefficient of $25001 \mathrm{~mol}^{-1} \mathrm{~cm}^{-1}$. At shorter wavelengths the extinction coefficient increases at $235 \mathrm{~nm}$ to 7500 $1 \mathrm{~mol}^{-1} \mathrm{~cm}^{-1}$, providing a more sensitive measurement. Application of lower wavelengths is limited by the quality and absorption of the eluent. In practice, no problems were encountered working at $235 \mathrm{~nm}$.

High demands are put on the quality of the eluent because of the abovementioned facts, but also to prevent the appearance of interfering peaks in the chromatograms.

\section{Quantitation}

The peak height ratio of galanthamine base to the internal standard phenacetin is used for quantitation. The peak height ratios for the serum standards are plotted against concentration to obtain a standard calibration curve. 


\section{RESULTS}

Typical chromatograms for serum samples containing 0 and $5 \mathrm{ng} / \mathrm{ml}$ galanthamine are presented in Fig. $4 a$ and $b$, respectively; phenacetin is added as internal standard.
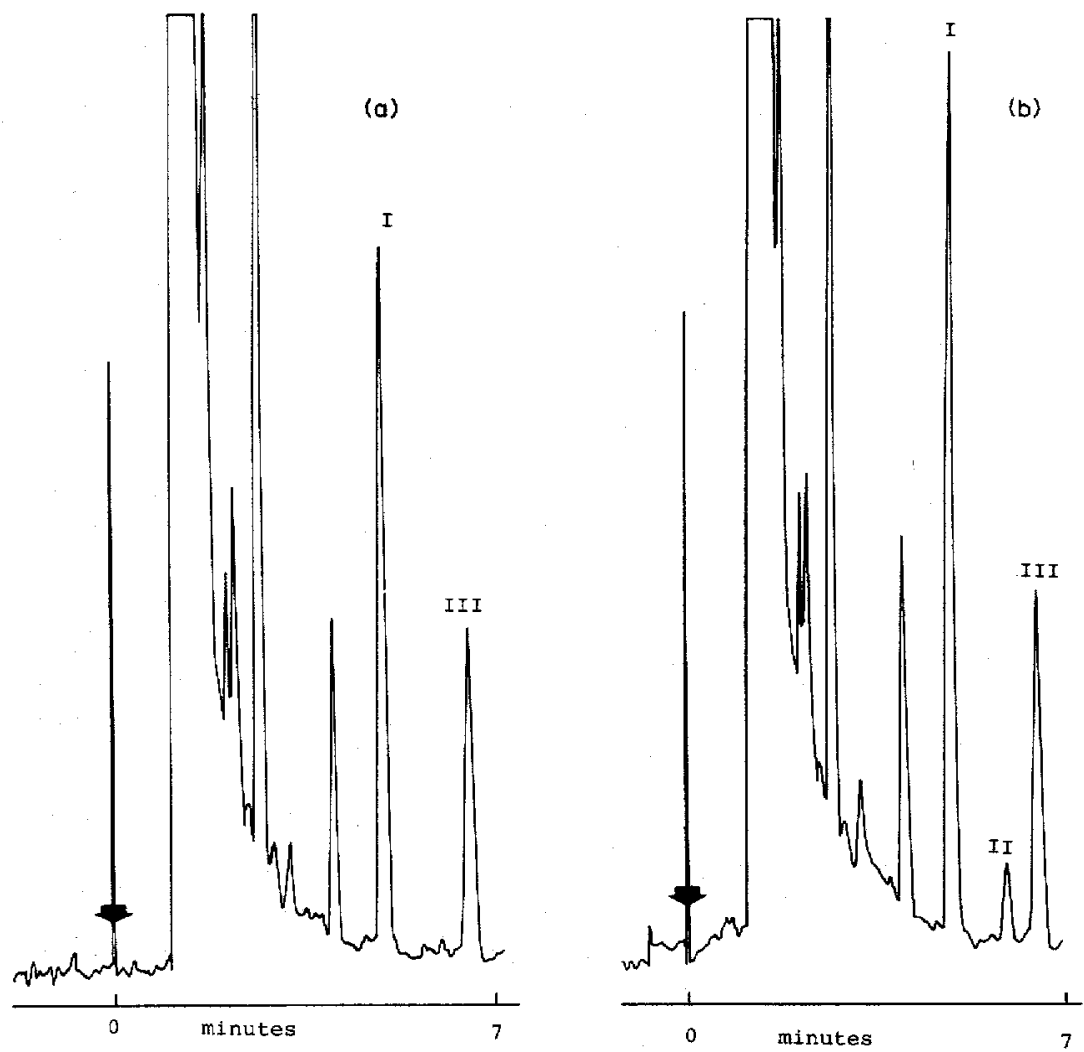

Fig. 4. Chromatograms of serum samples containing $0 \mathrm{ng} / \mathrm{ml}$ galanthamine (a) and $5 \mathrm{ng} / \mathrm{ml}$ galanthamine (b). Conditions: flow-rate $1 \mathrm{ml} / \mathrm{min}$; eluent $n$-hexane-dichloromethaneethanolamine $(500: 500: 0.25, \mathrm{v} / \mathrm{v}) ; 10 \mu \mathrm{l}$ injection; UV detection at $235 \mathrm{~nm}, 2.5 \times 10^{-3}$ a.u.f.s. $I$ = pollution of dichloromethane, $I I$ = galanthamine, $I I I=$ phenacetin.

\section{Calibration curve}

The galanthamine/phenacetin ratios, calculated after determination of the serum standards $10,20,40,50,70$, and $100 \mathrm{ng} / \mathrm{ml}$, are used for constructing a calibration curve. The correlation coefficient is calculated by a least-squares procedure and is equal to $0.9996(n=32)$.

\section{Precision and detection limit}

The precision of the assay method was assessed by repeated analysis, on different days, of serum samples containing various concentrations of galanthamine. Galanthamine serum levels were calculated by means of a calibration curve. The results are shown in Table I.

The detection limit of galanthamine base in serum is about $5 \mathrm{ng} / \mathrm{ml}$. The coefficient of variation at this level is $\mathbf{3 7 . 8 \%}$ as presented in Table I. 
TABLE I

PRECISION DATA

\begin{tabular}{lcclr}
\hline $\begin{array}{l}\text { Galanthamine } \\
\text { serum standards } \\
\text { (ng/ml) }\end{array}$ & $n \begin{array}{l}\text { Mean galanthamine } \\
\text { serum level assayed } \\
(\mathrm{ng} / \mathrm{ml})\end{array}$ & $\begin{array}{l}\text { S.D. } \\
(\mathrm{ng} / \mathrm{ml})\end{array}$ & \multicolumn{1}{l}{$\begin{array}{l}\text { C.V. } \\
(\%)\end{array}$} \\
\hline 5 & 4 & 3.20 & 1.21 & 37.8 \\
10 & 5 & 10.86 & 2.06 & 18.9 \\
20 & 5 & 20.22 & 1.93 & 9.5 \\
40 & 4 & 39.48 & 1.68 & 4.3 \\
50 & 8 & 48.79 & 2.06 & 4.2 \\
70 & 4 & 69.60 & 1.75 & 2.5 \\
100 & 6 & 101.0 & 2.56 & 2.5 \\
\hline
\end{tabular}

\section{Recovery study}

The recovery of galanthamine base was measured by assaying the galanthamine serum standard of $50 \mathrm{ng} / \mathrm{ml}$ eight times. Percentage recovery was calculated by comparing the peak height ratio galanthamine/phenacetin with the peak height ratio obtained by directly injecting solutions of the pure compounds. Galanthamine base showed an average recovery of $100.2 \%$ with a S.D. of $2.1 \%(n=8)$.

\section{DISCUSSION}

To develop a sensitive method, the chromatographic dilution, amongst other factors, should be as small as possible. The use of $3-\mu \mathrm{m}$ particles and keeping retention times small $\left(k^{\prime}<6\right)$ are necessary to achieve this. The development of the method was started by applying reversed-phase chromatography on octadecyl phases. The influence of methanol content, $\mathrm{pH}$ of the eluent and ion-pairing reagents like hexylsulfonate were investigated.

In spite of the available tools of this technique we failed to develop a satisfactory procedure. We observed in these chromatographic systems a decrease in plate number for galanthamine of $75 \%$ compared to test components. This might be an indication of non-ideal behaviour of galanthamine under these conditions.

The application of normal-phase chromatography on silica using a mixture of $n$-hexane-dichloromethane and ethanolamine as an eluent gave much better results. In the latter case we observed a decrease of $25 \%$ in the plate number for galanthamine compared to a test mixture, indicating the better thermodynamic conditions in this system.

The influence of the dichloromethane content in the eluent and the addition of ethanolamine are shown in Figs. 2 and 3.

Other amines without a hydroxyl group failed to induce the same effect as ethanolamine. The extraction procedure of galanthamine from serum was started with Sep-Pak (sample enrichment and purification) cartridges (Waters Assoc., Milford, MA, U.S.A.). Sep-Pak cartridges are packed with liquid chromatographic separating materials which retain specific classes of compounds while allowing other materials to pass through. We have done several experi- 
ments with Sep-Pak silica and $\mathrm{C}_{18}$ cartridges and solvents of different polarity. The extraction yield of galanthamine from Sep-Pak $\mathrm{C}_{18}$ after elution with dichloromethane at $\mathrm{pH} 9$ was approximately $100 \%$ but HPLC chromatograms showed a high background signal due to co-extracted endogenous serum compounds. This high background of signals did not allow determination of nanogram amounts of galanthamine. From the various attempts that we have made to find an isolation method for galanthamine from serum with low background signals in HPLC chromatograms, the liquid-liquid extraction method presented was derived. The clean-up procedure in the liquid-liquid extraction method, described in this article, is laborious, but makes the assay very specific and sensitive.

The concentration of galanthamine in serum, found by us in preliminary experiments in man, varied between 500 and $60 \mathrm{ng} / \mathrm{ml}$ during $3 \mathrm{~h}$, after an intravenous dose of $0.3 \mathrm{mg}$ of galan thamine hydrobromide per $\mathrm{kg}$ body weight.

The following drugs, frequently used in patients undergoing anaesthesia, did not interfere with the HPLC determination of galanthamine: morphine, atropine, succinylcholine, thiopental, fentanyl, digoxin, gentamycin and tobramycin. The study of interferences by other components of comedication is continuing.

In our experiments we found that the assay procedure presented is also suitable for the determination of galanthamine in urine and bile.

\section{CONCLUSION}

The presented HPLC assay procedure for galanthamine in serum, urine and bile is very sensitive and therefore suitable for use in studies of pharmacokinetics and bioavailability of galanthamine in man.

\section{ACKNOWLEDGEMENTS}

We gratefully acknowledge the criticism of Prof. Dr. Ir. C.A.M.G. Cramers and Prof. Dr. H. Wesseling, the expert technical assistance of Dr. G.A. Vermeer, and the secretarial assistance of Mrs. B. Schellekens.

\section{REFERENCES}

1 N.F. Proskurnina and A.P. Yakovleva, J. Gen. Chem. (U.S.S.R.), 22 (1952) 1889.

2 E.A. Stojanov, Anaesthesist, 13 (1964) 217.

3 D.A. Cozanitis, Anaesthesist, 6 (1971) 226.

4 J. DeAngelis and L.F. Walts, Anesth. Analg., 51 (1972) 196.

5 A. Baraka and D.A. Cozanitis, Anesth. Analg., 52 (1973) 832.

6 D.S. Paskov, H. Dobrev and N. Nikiforov, in Drugs and Respiration, Proceedings of the 2nd International Pharmacological Meeting, Prague, 20-23 August, 1963, Pergamon Press, New York, p. 113.

7 D.A. Cozanitis and E. Toivakka, Anaesthesia, 29 (1974) 581.

8 . D.A. Cozanitis and P. Rosenberg, Anaesthesist, 23 (1974) 302.

9 P. Westra, R. Sia, M.C. Houwertjes and H. Wesseling, in Anaesthesia (volume of summaries), Sixth European Congress of Anaesthesiology, London, 8-15 September, 1982.

10 A. Baraka and S. Harik, J. Amer. Med. Assoc., 238 (1977) 2293.

11 D.A. Cozanitis, Anaesthesist, 26 (1974) 649. 
12 A. Baraka, 5th European Congress of Anaesthesiology, No. 453, Excerpta Medica, Amsterdam, 1978, p. 105.

13 S.H. Hong, J.F. Li and R.X. Xu, Chih Wu Hsueh Pao, 23 (1981) 334.

14 F. Wurst, T. Prey, L. Puchinger and E. Bancher, J. Chromatogr., 188 (1980) 452.

$15 \mathrm{Zh}$. Stefanov, Farmatsiya (Sofia), 27 (1977) 4.

16 I.D. Kalashnikov, Issled. Obl. Lek. Stredstv., (1969) 228.

17 E.Z. Asoeva and E.N. Vergeichik, Nauchn Dokl. Vyssh. Shk., Biol. Nauki, 7 (1967) 98.

18 C.Y. Wu and J.J. Wittick, Anal. Chem., 49 (1977) 359.

19 K.E. Rasmussen, F. Tonnesen, B. Nielsen, B. Lunde and J. Roe, Medd. Nor. Farm. Selsk., 40 (1978) 117.

20 R. Verpoorte and A. Baerheim Svendsen, J. Chromatogr., 100 (1974) 227.

21 R. Verpoorte and A. Baerheim Svendsen, J. Chromatogr., 100 (1974) 231.

22 R. Verpoorte and A. Baerheim Svendsen, J. Chromatogr., 109 (1975) 441.

23 G. Hoogewijs, Y. Michotte, J. Lambrecht and D.L. Massart, J. Chromatogr., 226 (1981) 423. 